\title{
Analisis Kuantitas dan Kualitas Air dalam Pengembangan Pemanfaatan Sumber Daya Air Sungai di Kawasan Hutan Lindung Sungai Wain
}

\author{
Quantity and Quality Analysis of Waterfor Developing River Water Resources \\ Utilization in the Sungai Wain Protected Forest Area
}

\author{
Sukristiyono Sukristiyono ${ }^{1}$ \\ Program Pascasarjana, Fakultas Kehutanan \\ Universitas Gadjah Mada, Yogyakarta, Indonesia
}

\section{Ris Hadi Purwanto}

Departemen Manajemen Hutan, Fakultas Kehutanan

Universitas Gadjah Mada, Yogyakarta, Indonesia

\section{Hatma Suryatmojo}

Departemen Konservasi Sumberdaya Hutan, Fakultas Kehutanan Universitas Gadjah Mada, Yogyakarta, Indonesia

\section{Sumardi Sumardi}

Departemen Silvikultur, Fakultas Kehutanan

Universitas Gadjah Mada, Yogyakarta, Indonesia

Artikel Masuk : 4 Februari 2021

Artikel Diterima : 17 November 2021

Tersedia Online : 31 Desember 2021

\begin{abstract}
Abstrak: Peningkatan jumlah penduduk setiap tahun serta pertumbuhan ekonomi di Kota Balikpapan yang cukup tinggi memberikan dampak negatif terhadap lingkungan terkait pemanfaatan sumber daya air. Aktivitas manusia di kawasan hutan lindung telah menyebabkan degradasi dan deforestasi hutan lindung sehingga mengakibatkan sungai di dalamnya saat ini tidak mampu memenuhi kebutuhan air ketika musim kemarau. Penelitian ini bertujuan untuk menilai kelayakan air sungai di dalam hutan lindung Sungai Wain pada aspek kuantitas dan kualitasnya sebagai upaya penyediaan alternatif sumber air baku untuk pengembangan fasilitas perkotaan. Analisis sampel air dilakukan di Laboratorium Kesehatan Daerah, Dinas Kesehatan Kota Balikpapan. Hasil penelitian menunjukkan bahwa debit air sungai Wain sebesar $0,334 \mathrm{~m}^{3} / \mathrm{dt}$, sungai Bugis sebesar $0,258 \mathrm{~m}^{3} / \mathrm{dt}$ sedangkan sungai Sengkuang sebesar $0,032 \mathrm{~m}^{3} / \mathrm{dt}$. Kualitas fisik air dari ketiga sungai tersebut memenuhi standar baku mutu kesehatan lingkungan dan menunjukkan kualitas air baik. Kualitas kimia air pada umumnya menunjukkan nilai di bawah batas maksimal yang diperbolehkan kecuali parameter $\mathrm{pH}$ dan besi. Kualitas biologi air menunjukkan sungai Bugis
\end{abstract}

\footnotetext{
1 Korespondensi Penulis: Program Pascasarjana, Fakultas Kehutanan Universitas Gadjah Mada, Yogyakarta, Indonesia

Email: sukristiyono@gmail.com
} 
mempunyai jumlah total coliform yang tertinggi yaitu 920, sedangkan sungai lainnya mempunyai jumlah total coliform 350. Sedangkan hasil analisis bakteri Escherecia coli menunjukkan bahwa semua sampel air penelitian mengandung bakteri Escherecia coli melebihi jumlah maksimum yang diperbolehkan. Hasil penelitian ini dapat menjadi bahan pertimbangan bagi pemerintah kota Balikpapan untuk rencana pengembangan pemanfaatan air sungai di kawasan hutan lindung Sungai Wain.

Kata Kunci: debit air; degradasi dan deforestasi; Hutan Lindung Sungai Wain; kualitas air; lingkungan; sumber daya air,

\begin{abstract}
The increase in population every year and the relatively high economic growth in Balikpapan City have had a negative impact on the environment related to the use of water resources. Human activities in the protected forest areas have caused degradation and deforestation of protected forest areas resulting in the three rivers currently unable to meet water needs during the dry season. This study aims to assess the feasibility of river water in the Sungai Wain protected forest in terms of quantity and quality as an effort to provide alternative sources of raw water for the development of urban facilities. Analysis of water samples was carried out at the Regional Health Laboratory, Balikpapan City Health Office. The results showed that the Wain river water discharge was $0.334 \mathrm{~m}^{3} / \mathrm{s}$, the Bugis river was $0.258 \mathrm{~m}^{3} / \mathrm{s}$, while the Sengkuang river was $0.032 \mathrm{~m}^{3} / \mathrm{s}$. The physical quality of water from the three rivers meets the standards of environmental health quality standards. The chemical quality of water indicates the $\mathrm{pH}$ and iron parameters do not meet environmental health quality standards. The biological quality of water indicates the total number of coliform in Bugis river is 920; Wain River 350, and Sengkuang River 350. The results of analysis of Escherecia coli bacteria showed that the content of Escherecia coli bacteria exceeded the maximum allowed amount. The results of this research can be taken into consideration for the Balikpapan city government to plan the development of river water utilization in the Sungai Wain protected forest area.
\end{abstract}

Keywords: degradation and deforestation; environment; Sungai Wain Protected Forest; water discharge; water quality; water resources

\title{
Pendahuluan
}

Pada umumnya permasalahan sumber daya air berhubungan dengan waktu dan penyebaran aliran air. Banjir serta kekeringan merupakan dua bentuk akibat dari perilaku air yang kontras akibat dari transformasi keadaan tataguna lahan dan unsur meteorologi, khususnya intensitas hujan. Banyak pendekatan telah dilakukan untuk pemecahan permasalahan sumber daya air, semisal bermacam-macam pendekatan pengelolaan vegetasi bahkan upaya-upaya keteknikan lainnya. Daerah hulu merupakan awal dari aliran air, sehingga pengelolaan vegetasinya diharapan dapat menurunkan aliran sedimen yang menuju daerah hilir, sehingga dapat memperpanjang manfaat daerah penampungan air di bawahnya semisal waduk dari pendangkalan akibat sedimen dari daerah hulu (Asdak, 2010).

Kawasan hutan lindung merupakan kawasan hutan yang mempunyai karakteristik khas sehingga dapat memberikan perlindungan terhadap kawasan di sekitar ataupun di hilirnya sebagai pengelola tata air, pencegah banjir, erosi tanah dan pemelihara kesuburan tanah. Keberadaan hutan lindung sangat penting untuk dipertahankan karena peranannya dalam menjaga ekosistem. Pada umumnya kerusakan hutan lindung dimulai dengan masuknya masyarakat untuk mengakses sumberdaya yang ada di dalam hutan lindung. Ketika pemanfaatan ini melebihi daya dukung hutan tersebut maka akan mengakibatkan kawasan hutan mengalami degradasi ataupun deforestasi (Dako et al. 2019). 
Tingkat perkembangan pembangunan di Kota Balikpapan yang cukup pesat memberi pengaruh yang positif terhadap pertumbuhan sosial ekonomi masyarakat Balikpapan. Akan tetapi hal ini memberi pengaruh yang berkebalikan terhadap kondisi lingkungan kota Balikpapan. Maulana (2016) menyatakan bahwa kawasan hutan lindung di Kota Balikpapan terancam dan terganggu kelestariannya akibat adanya konversi lahan, aktivitas perkebunan masyarakat yang memberikan nilai ekonomi yang tinggi. Disamping itu aktivitas masyarakat yang dilakukan di badan sungai dan waduk mengakibatkan gangguan terhadap fungsi kawasan air tersebut seperti perubahan kondisi fisik pinggir dan dasar sungai serta waduk, gangguan aliran air sungai bahkan berpotensi menurunkan kualitas air sungai.

Hutan Lindung Sungai Wain (HLSW) terletak di Kota Balikpapan, Provinsi Kalimantan Timur pada ketinggian sekitar $600 \mathrm{~m}$ dpl dan mempunyai fungsi yang khas sebagai hutan lindung, antara lain sebagai kawasan resapan air dimana kawasan HLSW ini mempunyai kemampuan tinggi untuk meresapkan air hujan ke dalam tanah yang bermanfaat sebagai sumber air, mempertahankan kelestarian mata air, sungai dan waduk. Kawasan HLSW hulu berfungsi sebagai daerah tangkapan air (DTA) untuk waduk Wain yang berada di dalam areal HLSW bagian hilir. Air dari waduk Wain ini digunakan oleh masyarakat sekitar HLSW dan PT. Pertamina UP V Balikpapan sebagai bahan baku air untuk kegiatan industri dan pemenuhan kebutuhan air di komplek perumahan serta perkantoran perusahaan.

Berdasarkan data dari Pemerintah Kota Balikpapan (2014) bahwa waduk Wain mempunyai luas kurang lebih 25,49 ha, mendapat pasokan air dari 2 daerah aliran sungai (DAS) yang ada dalam kawasan HLSW. Kedua DAS tersebut adalah DAS Bugis (sungai Bugis) dan DAS Wain (sungai Wain dan sungai Sengkuang). DAS Bugis mempunyai DTA seluas kurang lebih 3.492 ha, sedangkan DAS Wain mempunyai luas DTA yang lebih besar yaitu kurang lebih 4.290 ha. Pada areal hutan lindung Sungai Wain terdapat instalasi rumah pompa air baku milik Pertamina berlokasi di pinggir waduk Wain, terdapat juga Kebun Raya Balikpapan (KRB) yang berstatus sebagai KHDTK seluas 309,22 ha sesuai No.SK.68/Menhut-II/2009 tanggal 6 Februari 2009 dan juga terdapat izin pemanfaatan hutan berupa Izin Usaha Pemanfaatan Hutan Kemasyarakatan (IUPHKm) seluas 1.416,90 ha diterbitkan berdasarkan surat keputusan Menteri Kehutanan No.SK.718/MenhutII/2014 Tanggal 29 Agustus 2014 (KPHL Balikpapan, 2017).

Pemanfaatan kawasan HLSW yang semakin lama semakin meningkat berdampak langsung maupun tidak langsung terhadap kualitas air sungai yang ada di dalamnya. Ketika suatu lingkungan ditambahkan atau ketambahan bahan materi pencemar sehingga menyebabkan gangguan terhadap makhluk hidup yang berada di dalamnya maka dapat disimpulkan bahwa lingkungan tersebut tercemar. Untuk itu kondisi lingkungan menjadi sangat penting diperhatikan dimana setiap ekosistem hutan baik di daratan maupun di pesisir dapat menjadi gambaran kualitas lingkungan apakah sudah berada dalam ambang tercemar atau belum (Matatula et al. 2019b). Pertambahan penduduk mempunyai korelasi negatif terhadap sumber daya air baik dari segi kuantitas ataupun segi kualitas (Widiyanto et al. 2015). Pencemaran yang terjadi pada air melingkupi air yang berada pada daratan sampai perairan dimana aktivitas manusia menjadi penyebab utama (Poedjirahajoe \& Matatula, 2019). Perubahan warna dan bau pada air merupakan salah satu indikator adanya penurunan kualitas air. Ketika kualitas air sungai sudah tidak sesuai lagi dengan peruntukannya, maka sungai tersebut sudah tercemar (Pohan et al. 2016)

Air merupakan sumber daya alam yang dapat diperbarui, tetapi air akan dengan mudah terkontaminasi oleh aktivitas manusia. Ketersediaan sumber daya air untuk suatu peruntukan sangat tergantung pada kualitas sumber daya air tersebut. Kualitas dan kualitas air yang baik akan mengakomodasi kegiatan usaha atau pembangunan yang lebih beragam, seperti suplai air untuk kebutuhan domestik, pertanian, perikanan, industri maupun rekreasi. Hutan Lindung Sungai Wain (HLSW) pada mulanya dikenal sebagai "Hutan 
Tutupan” yang ditetapkan oleh Sultan Kutai pada Tahun 1934 dengan Surat Keputusan Pemerintah Kerajaan Kutai No.48/23-ZB-1934 sebagai Hutan Lindung. Kawasan HLSW terletak antara Balikpapan dan Samarinda, sekitar $40 \mathrm{~km}$ dari Balikpapan. HLSW merupakan kombinasi antara hutan primer (hutan asli) dan hutan sekunder (hutan buatan pengganti hutan yang terbakar ditahun 1997/1998). Kawasan HLSW bermanfaat sebagai daerah tangkapan air yang digunakan masyarakat dan para penduduk yang berada di sekitar hutan, sejak 52 tahun yang lalu telah digunakan sebagai tempat pengolahan dan persediaan air yang digunakan untuk suplai industri minyak di kota Balikpapan (Kubah et al., 2018).

Menurut KPHL Balikpapan (2017) berbagai peristiwa kebakaran hutan selama beberapa tahun belakangan ini melanda kawasan HLSW mengakibatkan kerusakan ekosistem hutan lindung tersebut, menurunnya tutupan lahan hutan serta menurunnya fungsi hutan lindung itu sendiri. Kebakaran terbesar pada dekade terakhir ini terjadi pada tahun 2015, dimana kurang lebih 1.000 ha areal HLSW terbakar. Sebagian besar areal yang terbakar berada di bagian hulu kawasan HLSW yang merupakan daerah tangkapan air (DTA) bagi beberapa DAS yang ada di dalam kawasan HLSW. Kondisi seperti ini dapat menjadi ancaman untuk kelestarian ketersediaan air di masa depan mengingat bahwa kondisi hutan di bagian hulu sangat berpengaruh besar terhadap sumber daya air bagi sungai-sungai yang ada di dalam HLSW dan bagi masyarakat yang berada di bagian hilir kawasan HLSW.

Kebutuhan ketersediaan air bersih, sehat dan aman untuk memenuhi kebutuhan hidup manusia jika kita tinjau dari segi kualitas air minum siap konsumsi maka tersedia hanya sekitar 0,03\% (Oktavianto et al., 2014). Oleh karenanya dibutuhkan keterlibatan masyarakat dalam mengkonservasi sumber daya air dengan pola kearifan local (Pathibang et al., 2019). Bahkan dibeberapa tempat telah menerapkan teknologi agroforestri dengan sistem sylvopastura sebagai bagian untuk melibatkan masyarakat dalam mengelola lahanlahan untuk ketersediaan air (Matatula, 2009). Salah satu kelurahan di sekitar kawasan HLSW yang memerlukan penyediaan air bersih adalah Kelurahan Karang Joang, Kecamatan Kecamatan Balikpapan Utara, Kota Balikpapan. Daerah tersebut sering mengalami kesulitan air bersih ketika musim kemarau tiba. Terjadi penurunan kuantitas dan kualitas air yang disebabkan antara lain menurunnya debit air sungai yang ada di dalam kawasan HLSW serta pencemaran air sungai oleh mikrobiologi terutama bakteri indikator sanitasi golongan koliform.

Penelitian sebelumnya pernah mengkaji bentuk pemanfaatan sumber daya air yang berasal dari kawasan HLSW serta tingkat konsumsi air masyarakat sekitar hutan dan PT.Pertamina (Yusuf, 2010). Masyarakat yang menggunakan air secara langsung ke sungai untuk minum, mandi, cuci dan kakus pada umumnya adalah yang berada di dalam hutan dan di perbatasan kawasan HLSW. Adapun masyarakat yang berada agak jauh dari kawasan hutan menggunakan sumur untuk memenuhi kebutuhan air. Bentuk pemanfaatan air oleh PT Pertamina adalah untuk proses produksi serta komplek perkantoran dan perumahan karyawan. Penelitian tersebut lebih terfokus pada besaran konsumsi air masyarakat dan perusahaan serta bentuk pemanfaatannya, belum memperhatikan aspek kuantitas dan kualitas air pada sungai-sungai yang ada di dalam kawasan HLSW.

Menurut (Ningsih et al., 2020) dalam penelitiannya yang terfokus pada kondisi kesetimbangan neraca air disebutkan bahwa keterbatasan ketersediaan air dan penurunan kualitas air sungai dapat menjadi indikator bahwa kondisi DAS telah mengalami kerusakan dan berdampak terhadap keberlanjutan sumber daya air. Sungai mempunyai peranan yang sangat dibutuhkan bagi kehidupan masyarakat, disamping pemanfaatan aliran air, aktivitas manusia sangat mempengaruhi kondisi sungai. Pemenuhan kebutuhan air bersih, masyarakat di sekitar kawasan HLSW sangat bergantung kepada air yang ada di waduk Wain. 
Sarminah et al. (2020) dalam penelitiannya tentang kualitas air pada DAS Bugis dan DAS Wain di kawasan HLSW menunjukkan bahwa kualitas air pada DAS Bugis dan DAS Wain dapat digunakan untuk air minum atau keperluan konsumsi lainnya, budidaya perikanan, pengairan tanaman dan sarana rekreasi air. Namun penelitian tersebut hanya menggunakan sungai Wain dan sungai Bugis, belum mengkaji secara menyeluruh sungaisungai yang ada di dalam kawasan HLSW serta kuantitas air dari setiap sungainya. Berbeda dengan penelitian-penelitian sebelumnya, penelitian ini lebih terarah pada kajian terkait kelayakan pengembangan pemanfaatan sumber daya air sungai di kawasan HLSW. Penelitian ini bertujuan untuk menilai kelayakan air sungai di dalam hutan lindung Sungai Wain pada aspek kuantitas dan kualitasnya sebagai upaya penyediaan alternatif sumber air baku untuk pengembangan fasilitas perkotaan. Aspek kuantitas sangat penting mengingat Kota Balikpapan merupakan kota dengan perkembangan penduduk yang cukup tinggi dan pertumbuhan ekonomi yang pesat sebagai pintu masuk provinsi Kalimantan Timur. Sedangkan, kualitas sumber daya air penting untuk diperhatikan karena kawasan pertanian dan perkebunan yang berada di sekitar sumber air dapat mencemari sumber daya air yang ada.

\section{Metode Penelitian}

Penelitian ini dilakukan pada tiga sungai yang ada di dalam kawasan HLSW, yaitu sungai Bugis, sungai Wain, dan sungai Sengkuang, Kota Balikpapan, Provinsi Kalimantan Timur. Penelitian dilakukan pada bulan Maret 2019. Dalam penelitian ini menggunakan beberapa metode meliputi metode survey, metode uji laboratorium, metode matematis, dan metode evaluasi. Kegiatan yang dilakukan dalam metode survey meliputi pengamatan, pengukuran, wawancara, dan pencatatan hal-hal yang penting yang berkaitan dengan penelitian. Dalam penelitian ini metode uji laboratorium digunakan untuk menganalisis kualitas air. Sedangkan metode matematis digunakan untuk untuk mengolah data lapangan dengan menggunakan perhitungan dengan rumus-rumus, dan kaidah-kaidah yang ada. Kemudian hasil dari pengolahan data pengukuran di lapangan dan data hasil uji laboratorium dibandingkan dengan standar baku mutu kesehatan lingkungan. Kegiatan wawancara dan pengamatan langsung dilakukan terhadap masyarakat yang berada di sekitar kawasan HLSW. Penentuan responden dilakukan secara random sampling. Pengambilan data melalui teknik wawancara langsung dengan bantuan kuesoner yang terstruktur. Jumlah masyarakat yang menjadi responden dalam penelitian ini adalah 350 orang. Metode evaluasi digunakan sebagai metode terakhir untuk mencapai tujuan penelitian ini. Data yang dikumpulkan dalam penelitian ini adalah debit air; kualitas fisik air, kimia air, dan biologi air.

Penentuan titik sampling untuk pengambilan sample air langsung dilakukan pada ketiga sungai tersebut sekaligus dengan pengukuran debit air. Metode yang digunakan dalam pengukuran debit air adalah Metode Apung (Floating Method). Rumus debit air dalam Metode Apung dapat dilihat pada persamaan (1).

$$
\mathrm{Q}=\mathrm{V} \times \mathrm{A}
$$

Keterangan: $\mathrm{Q}=$ Debit ( $\mathrm{m}^{3} /$ detik), $\mathrm{V}=$ Kecepatan aliran $(\mathrm{m} / \operatorname{detik})$, dan $\mathrm{A}=$ Luas penampang basah $\left(\mathrm{m}^{2}\right)$

Sedangkan analisis kualitas fisik air (warna, bau, rasa), kimia air $\left\{\mathrm{pH}\right.$, Sulfat $\left(\mathrm{SO}_{4}{ }^{2-}\right)$, Besi $\left(\mathrm{Fe}^{3+}\right)$, Kesadahan $\left(\mathrm{CaCO}_{3}\right)$, Klorida $(\mathrm{Cl})$ \} dan biologi air (total coliform dan escherecia coli) dilakukan di Laboratorium Dinas Kesehatan Kota Balikpapan. Pengujian kualitas air dilakukan dengan mengacu pada standar baku mutu sesuai dengan Peraturan Menteri 
Kesehatan RI No. 32/MENKES/2017 tentang Standar Baku Mutu Kesehatan Lingkungan untuk Keperluan Higiene Sanitasi (Kementerian Kesehatan, 2017.

\section{Hasil dan Pembahasan}

Sejak dikeluarkannya Undang-Undang Nomor 23 tahun 2014 tentang Pemerintah Daerah dan kemudian direvisi dengan Undang-Undang nomor 09 tahun 2015, maka pengelolaan hutan lindung Sungai Wain menjadi di bawah wewenang Dinas Kehutanan Provinsi Kalimantan Timur yang diselenggarakan oleh KPHL Balikpapan. HLSW yang memiliki luas total 11.245,95 ha merupakan bagian dari areal kerja KPHL Balikpapan. Secara admistratif kawasan HLSW bagian barat masuk dalam Kelurahan Kariangau (Kecamatan Balikpapan Barat) dan bagian timur masuk dalam Kelurahan Karang Joang (Kecamatan Balikpapan Utara). Pada bagian utara HLSW berbatasan dengan Desa Mentawir (Kabupaten Penajam Paser Utara) dan Kelurahan Sungai Merdeka (Kabupaten Kutai Kartanegara), yang keduanya merupakan areal kerja IUPHHK-HT. PT. Inhutani I Batu Ampar Balikpapan. HLSW mempunyai fungsi sebagai sistem penyangga kehidupan untuk mengatur tata air, mencegah banjir dan erosi, menjaga kesuburan tanah, melindungi sumber plasma nutfah serta mencegah intrusi air laut. Peta lokasi penelitian seperti pada Gambar 1.

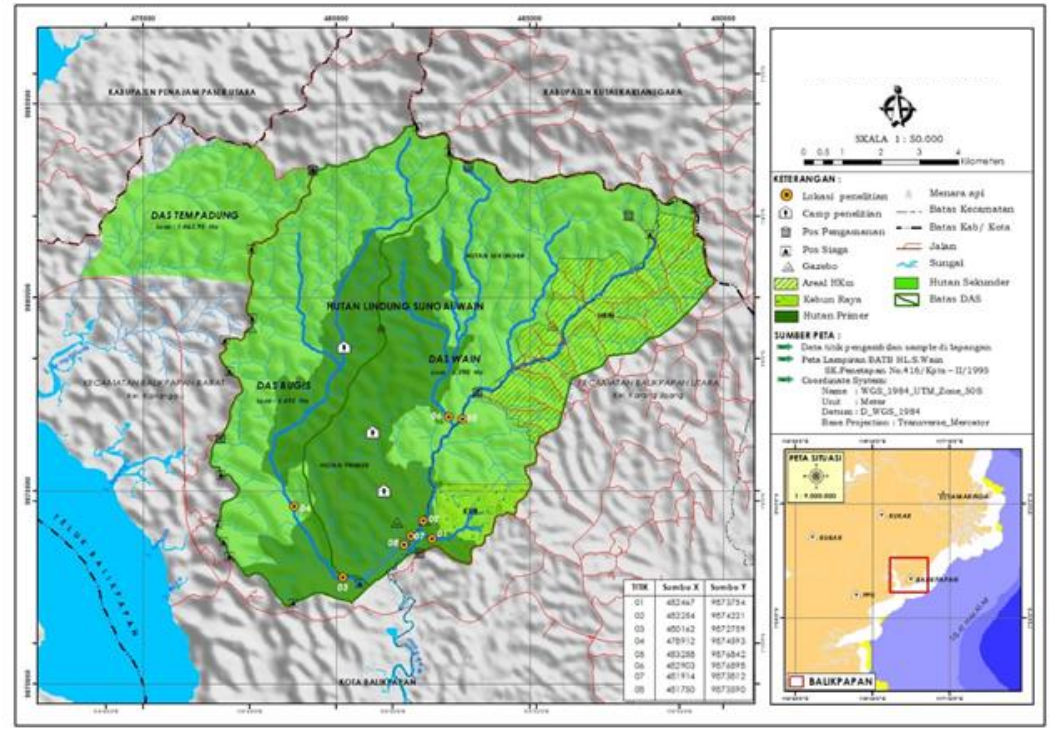

Gambar 1. Peta Lokasi Penelitian di Hutan Lindung Sungai Wain, Kota Balikpapan

\section{Kebutuhan Air Masyarakat}

Berdasarkan hasil wawancara kuesioner kebutuhan domestik, diketahui bahwa sumber air untuk memenuhi kebutuhan harian penduduk diperoleh dari sumur pribadi, sumur umum, bak penampungan air hujan dan langsung dari sungai. Masyarakat yang berada di kawasan yang berbatasan langsung dengan HLSW serta dekat sungai pada umumnya memperoleh air untuk minum, mandi, cuci dan kakus dari sungai atau mata air, sedangkan yang menggunakan sumur adalah masyarakat yang di luar kawasan HLSW dan berada agak jauh dari sungai. Sumber air yang paling banyak digunakan oleh masyarakat adalah sumur pribadi $(81,14 \%)$. Masyarakat yang menggunakan sungai secara langsung untuk memenuhi kebutuhan hariannya sebesar 9,71\% (Gambar 2). 
Triatmodjo (2010) menyatakan bahwa kegiatan harian yang paling sedikit dan paling banyak membutuhkan air di antaranya adalah untuk mengepel, menyiram bunga, minum ternak, menyiram halaman, memasak, mencuci alat dapur, minum, kakus, kegiatan lain, memandikan ternak, mencuci pakaian dan mandi. Kegiatan mandi mencapai 26\% dari kebutuhan air total. Rata-rata kebutuhan air untuk mandi sebesar 81 liter/orang/hari. Kebutuhan harian penduduk pedesaan umumnya adalah 82,5 liter/individu/hari. Sumber lainnya menyatakan bahwa kebutuhan air penduduk pedesaan tidak lebih dari 100 liter/individu/hari. Sementara kebutuhan air masyarakat di dalam dan di sekitar HLSW ini diketahui sebesar 98,54 liter/individu/hari. Besarnya kebutuhan air domestik ini kemungkinan dipengaruhi oleh tingkat kesejahteraan dan standar hidup, kebiasaan atau budaya, tingkat ketersediaan air, iklim, biaya dan sumber alternatif. Kebutuhan air domestik setiap orang berbeda-beda karena dipengaruhi oleh banyak faktor, di antaranya faktor usia, pekerjaan, kegiatan rumah tangga, lingkungan dan ketersediaan air (Gambar 3).
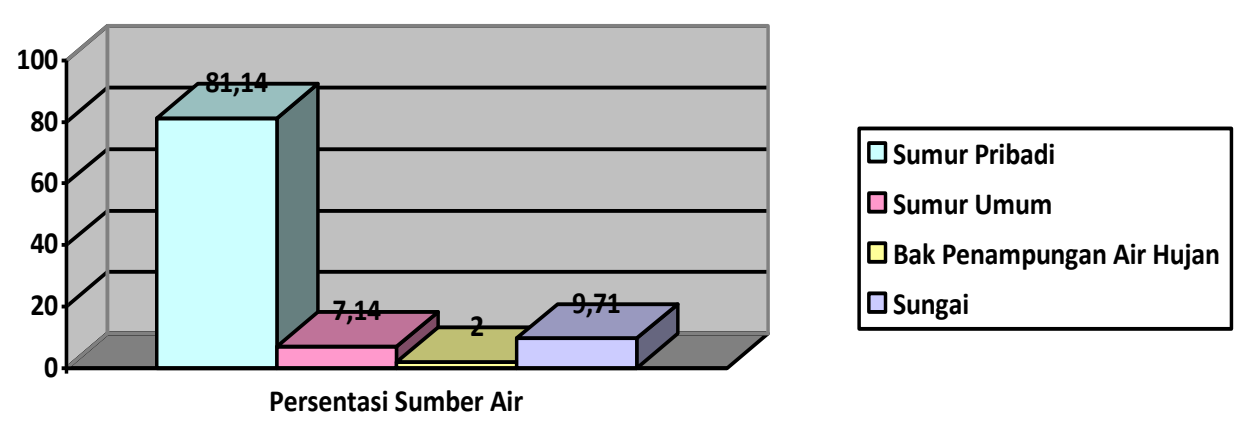

\section{Gambar 2. Persentase Sumber Air yang Digunakan Masyarakat di Sekitar HLSW}
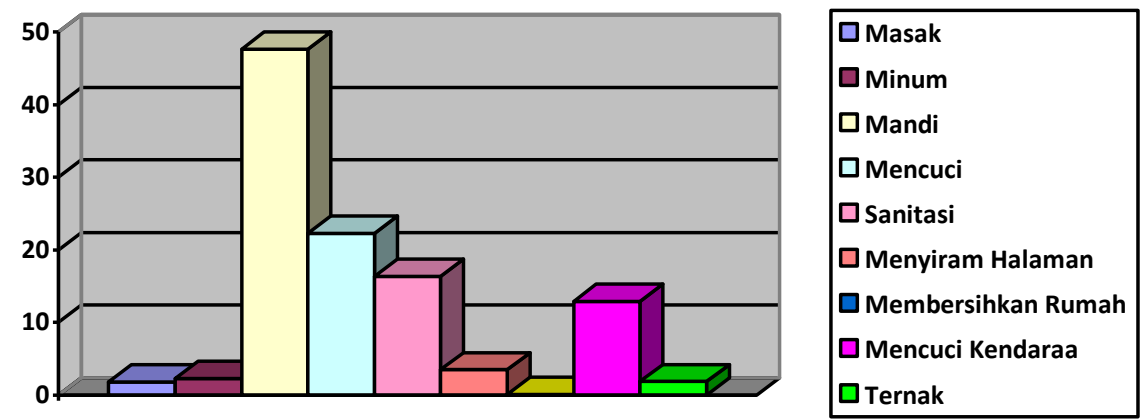

\section{Gambar 3. Kebutuhan Air Domestik di Sekitar HLSW}

\section{Kuantitas Air}

Terdapat tiga sungai di dalam kawasan HLSW yatu sungai Wain, sungai Sengkuang, dan sungai Bugis. Air dari ketiga sungai tersebut mengalir menuju ke waduk Wain (waduk Pertamina). Air dari waduk ini dimanfaatkan oleh masyarakat sekitar HLSW untuk memenuhi kebutuhan domestik, dan juga dimanfaatkan oleh PT. Pertamina UP V Balikpapan sebagai sumber air baku untuk memenuhi kebutuhan industri dan komplek perumahan Pertamina di Balikpapan. Berdasarkan pengguna air menunjukan hubungan antara masyarakat sebagai pengguna dan juga dimanfaatkan Pertamina untuk kebutuhan 


\section{Analisis Kuantitas dan Kualitas Air dalam Pengembangan Pemanfaatan Sumber Daya Air . .}

industri. Hal ini sejalan dengan pendapat Aronggear et al. (2019) yang menjelaskan bahwa kuantitas air merupakan besaran kebutuhan air bersih yang dimanfaatkan untuk memenuhi kebutuhan tiap hari, sehingga kuantitas air dapat tergambarkan dengan jumlah pemakaian air pada setiap lokasi. Dari penelitian ini diperoleh hasil sebanyak 98,29\% responden menginginkan adanya jaringan distribusi air bersih yang baik untuk memenuhi kebutuhan air bersih bagi masyarakat di sekitar kawasan HLSW. Dalam merencanakan sistem penyediaan air di daerah, proyeksi penggunaan air harus dihitung secara tepat dalam memanfaatkan air bersih pada lokasi tersebut. Ketika suatu daerah mulai berkembang perekonomiannya maka akan menyebabkan aglomerasi sehingga fasilitas-fasilitas untuk memenuhi kebutuhan masyarakat harus sudah direncanakan dan dipersiapkan. Salah satunya adalah kebutuhan air bersih untuk masyarakat sehingga sumber air alternatif harus sudah dipersiapkan ketersediaannya.

Tabel 1. Potensi Debit Air Sungai di dalam Kawasan HLSW

\begin{tabular}{|c|c|c|c|c|c|}
\hline Lokasi Pengukuran & $\begin{array}{c}\text { Debit } \\
\left(\mathrm{m}^{3} / \mathrm{dt}\right)\end{array}$ & $\begin{array}{l}\text { Debit } \\
\text { (lt/dt) }\end{array}$ & $\begin{array}{c}\begin{array}{c}\text { Debit } \\
\left(\mathrm{m}^{3} / \text { hari) }\right.\end{array} \\
\end{array}$ & $\begin{array}{c}\text { Debit } \\
\text { (It/hari) }\end{array}$ & $\begin{array}{c}\text { Kelas } \\
\text { Kuantitas } \\
\end{array}$ \\
\hline Sungai Wain & 0,334 & 334 & 28.863 & 28.863 .617 & Besar \\
\hline Sungai Bugis & 0,258 & 258 & 22.279 & 22.279 .414 & Besar \\
\hline Sungai Sengkuang & 0,032 & 32 & 2.804 & 2.804 .136 & Besar \\
\hline
\end{tabular}

Berdasarkan hasil analisis debit air sungai pada ketiga sungai di lokasi penelitian yang ditunjukkan pada Tabel 1 dapat dinyatakan bahwa kuantitas debit air ketiga sungai tersebut termasuk dalam kategori potensi besar, debit harian yang dihasilkan melebihi $100 \mathrm{~m}^{3} / \mathrm{hari}^{2}$ atau $100.000 \mathrm{lt} /$ hari. Debit harian sungai Wain mencapai $28.863 \mathrm{~m}^{3} /$ hari, sungai Bugis mencapai $22.279 \mathrm{~m}^{3} /$ hari. Sedangkan besarnya debit air sungai Sengkuang sebesar 2.804 $\mathrm{m}^{3} /$ hari. Perbedaan yang cukup besar ini dikarenakan luas daerah tangkapan air (DTA) pada DAS Wain dan DAS Bugis lebih besar daripada luas DTA sungai Sengkuang. DAS Wain memiliki luas sebesar 6.290 ha dan DAS Bugis memiliki luas sebesar 3.492 ha, sedangkan sungai Sengkuang mempunyai daerah DTA sebesar 309 ha. Disamping itu kawasan DAS Wain dan DAS Bugis masih memiliki tegakan hutan primer (virgin forest) dengan kondisi tegakan yang rapat alami. Hal ini akan mempengaruhi luas penutupan lahan hutan, sehingga akan mengakibatkan infltrasi air hujan ke dalam lahan hutan meningkat. Peningkatan infiltrasi air akan memperbesar air yang disimpan dalam tanah. Air yang tersimpan di dalam tanah adalah air yang perlahan-lahan muncul kepermukaan sebagai mata air. Nilai-nilai faktor penutupan lahan mempunyai hubungan linear negatif terhadap nilai-nilai debit sungai, artinya setiap ada perubahan nilai luas penutupan lahan akan diikuti dengan perubahan nilai debit sungai (Wahid, 2009).

Asdak (2010) menjelaskan bahwa pohon memiliki konstribusi yang nyata pada konservasi sumber daya air, melalui bagian-bagian dari pohon seperti: tajuk pohon berperanan menghambat laju butiran-butiran air hujan supaya tidak langsung jatuh ke permukaan tanah; air hujan ditahan oleh daun-daun kemudian sebagian mengalir melalui batang pohon sebagai aliran batang sehingga laju airnya berkurang untuk sampai permukaan tanah; dan perakaran pohon dan tumbuhan bawah dapat membantu air hujan masuk ke dalam pori-pori tanah dan meningkatkan infiltrasi tanah sehingga meningkatkan air yang tersimpan di dalam tanah. Tanah yang mempunyai vegetasi di atasnya dapat menjaga kestabilan debit air sepanjang masa.

Lebih lanjut dijelaskan bahwa besarnya debit suatu sumber mata air juga dipengaruhi oleh curah hujan (Sudia et al. 2011). Curah hujan yang jatuh akan mempengaruhi besarnya aliran permukaan dan jumlah air yang masuk ke dalam tanah melalui infiltrasi. Besarnya 
laju infiltrasi dipengaruhi oleh beberapa faktor di antaranya tekstur tanah, struktur tanah, bahan organik, ruang pori tanah dan aktifitas organisme tanah.

Mersianty \& Mahfud (2017) dalam penelitiannya menyatakan bahwa kota Balikpapan hingga sampai saat ini masih mengalami permasalahan krisis air baku. Dengan jumlah penduduk kota Balikpapan \pm 689.000 jiwa, kebutuhan masyarakat akan air bersih belum semuanya mendapatkan pelayanan air bersih, sekitar $82 \%$ dari jumlah penduduk yang dapat dilayani. Kecenderungan permasalahan defisit air tersebut tiap tahunnya meningkat. Disamping itu permasalahan pencemaran yang dapat menurunkan kualitas air dan permasalahan kebocoran sistem suplai air baku masih harus dihadapi pemerintah kota Balikpapan. Oleh karena itu kuantitas air pada tiga lokasi penelitian memberikan gambaran ketersediaan air yang dapat digunakan dalam rancangan pengelolaan dengan baik sehingga masuk dalam suatu perencanaan pengembangan pengelolaan air yang dapat menambah suplai air baku pada kota Balikpapan.

\section{Kualitas Air}

Parameter yang digunakan dalam pengujian kualitas air sungai pada penelitian ini adalah parameter fisik, parameter kimia dan parameter biologi. Analisis laboratorium untuk beberapa parameter tersebut dilakukan di UPTD Laboratorium Kesehatan Daerah, Dinas Kesehatan Kota Balikpapan. Dari hasil wawancara dengan masyarakat didapatkan 82,57\% responden menyatakan bahwa kondisi sumber air yang ada dapat/layak dikonsumsi/diminum tetapi harus dilakukan penyaringan dan penjernihan terlebih dahulu sebelum dimasak. Sedangkan $17,43 \%$ responden menyatakan tidak layak untuk dikonsumsi/diminum dikarenakan kondisi airnya keruh, kotor, dan berbau. Sebagai alternatif pemenuhan air konsumsi/minum sebanyak 43,14\% responden membeli air tangki atau air galon isi ulang.

\section{Parameter Fisik}

Dari hasil pengamatan di lapangan secara langsung, kualitas fisik air dari ketiga sungai tersebut terlihat relatif baik. Indikator yang digunakan dalam penelitian untuk dijadikan parameter kualitas fisik air adalah kekeruhan, warna, TDS, suhu, rasa, dan bau. Sifat fisik adalah sifat yang dapat dlihat secara langsung oleh mata dan indera lainnya. Perubahan warna dan bau air merupakan tanda bahwa telah terjadi penurunan kualitas air (Pohan et al. 2016).

Tabel 2. Kualitas Fisik Air Sungai

\begin{tabular}{clcccccc}
\hline No. & $\begin{array}{c}\text { Lokasi Pengambilan } \\
\text { Sampel air }\end{array}$ & $\begin{array}{c}\text { Kekeruhan } \\
(\mathbf{N T U})\end{array}$ & $\begin{array}{c}\text { Warna } \\
(\mathbf{T C 1}, \mathbf{4 U})\end{array}$ & $\begin{array}{c}\text { TDS } \\
(\mathbf{m g} / \mathbf{L})\end{array}$ & $\begin{array}{c}\text { Suhu } \\
\left({ }^{\mathbf{}} \mathbf{C}\right)\end{array}$ & Rasa & Bau \\
\hline 1. & Sungai Wain & 17,2 & 2,8 & 7 & 27,0 & Tidak & Tidak \\
2. & Sungai Bugis & 12,2 & 1,4 & 13 & 27,7 & Tidak & Tidak \\
3. & Sungai Sengkuang & 19,3 & 2,4 & 13 & 26,9 & Tidak & Tidak \\
& Kadar Maksimum & 25,0 & 50,0 & 1500 & Suhu udara & - & - \\
\hline
\end{tabular}

Hasil uji laboratorium pada Tabel 2 menunjukkan air pada sungai Wain, sungai Bugis dan sungai Sengkuang tidak berasa dan tidak berbau. Nilai kekeruhan sungai Wain 17,2 NTU, sungai Bugis 12,2 NTU, dan sungai Sengkuang 19,3 NTU, semua mata air berada di bawah nilai baku mutu maksimal yang diperbolehkan 25 NTU. Kegiatan pembangunan fisik seperti pembuatan bangunan, pembuatan jalan, pembuatan embung-embung, berakibat meningkatnya areal terbuka di areal KHDTK Kebun Raya Balikpapan yang merupakan kawasan DTA sungai Sengkuang. Hal tersebut diduga menjadi penyebab dari tingginya 
nilai kekeruhan sungai Sengkuang. Sedangkan nilai kekeruhan sungai Wain dipengaruhi adanya pembukaan kawasan hutan di bagian hulu sungai Wain untuk pelaksanaan program kegiatan Hutan Kemasyarakatan $(\mathrm{HKm})$. Berbeda dengan kondisi kawasan hulu sungai Bugis yang merupakan kawasan hutan yang sebagian terbuka yang disebabkan oleh kebakaran hutan. Hal-hal tersebut menyebabkan terjadinya erosi tanah ketika musim hujan dan mengalir ke sungai sehingga mengakibatkan kekeruhan air sungai yang pada akhirnya akan terjadi pendangkalan. Berdasarkan hasil wawancara dengan masyarakat, bahwa $90 \%$ responden menyatakan kondisi air sungai di kawasan HLSW saat ini lebih buruk/keruh dibanding 10 tahun sebelumnya. Gambaran nilai kekeruhan juga harus menjadi pertimbangan dalam rancangan pengelolaan air pemerintah Balikpapan sebelum melakukan perencanaan pemanfaatan air untuk kebutuhan kota Balikpapan. Kajian ini sesuai dengan pendapat para ahli yang menyatakan bahwa kualitas air menjadi priritas utama sebelum didistribusikan kepada pengguna air di suatu kota (Suheri et al., 2019).

Air dikatakan baik jika mempunyai suhu yang tidak berbeda dengan suhu udara berkisar antara $20^{\circ} \mathrm{C}-30^{\circ} \mathrm{C}$, dan Ketika air memiliki suhu berada di bawah atau di atas suhu udara menandakan bahwa air tersebut sudah tercemar (Hasrianti \& Nurasia, 2016). Suhu air dapat berbeda-beda sesuai dengan kondisi iklim, waktu pada saat pengambilan sampel air, dan kondisi lapangan. Suhu air dinyatakan dalam keadaan normal jika kondisi suhu berkisar $25^{\circ} \mathrm{C}-29^{\circ} \mathrm{C}$. Hasil pengukuran menunjukan suhu tertinggi berada pada sungai Bugis yang mencapai $27,7^{\circ} \mathrm{C}$, kemudian sungai Wain $27^{\circ} \mathrm{C}$ dan yang terendah sungai Sengkuang $26,9^{\circ} \mathrm{C}$. Hal ini dimungkinkan karena areal di sekitar sungai Bugis cukup terbuka sehingga badan air yang terkena sinar matahari langsung lebih luas dan intensitas sinar matahari cukup tinggi. Disamping itu faktor lain yang mempengaruhi suhu air sungai adalah penutupan lahan bantaran sungai oleh vegetasi dan intensitas sinar matahari langsung pada permukaan air sungai. Hubungan intensitas radiasi sinar matahari yang mengenai badan air dengan suhu air sungai adalah linear positif. Semakin lama air sunga menerima paparan radiasi sinar matahari maka semakin meningkat pula panas yang diterima sehingga menaikkan suhu air sungainya. Fungsi ekologi yang dimiliki oleh vegetasi antara lain sebagai pengatur temperatur dan kelembaban udara, pemasok oksigen, penyerap karbondioksida (Sittadewi, 2008).

Warna air tidak selalu jernih meskipun tidak dalam kondisi terpolusi, namun biasanya air yang terpolusi memiliki warna tidak normal yang disebabkan oleh adanya bahan-bahan terlarut dan bahan-bahan tersuspensi, termasuk yang bersifat koloid (Srikandi, 1992). Warna dengan nilai tertinggi terdapat pada sungai Wain sebesar 2,8 TCU (True Color Unit), kemudian sungai Sengkuang 2,4 dan yang terendah adalah sungai Bugis sebesar 1,4 TCU. Sungai Wain mempunyai nilai yang lebih tinggi dikarenakan di salah satu bagan hulu dari DAS Wain merupakan areal Hutan Kemasyarakatan $(\mathrm{HKm})$ dimana terdapat lahan pertanan yang menghasilkan residu pertanian seperti pestisida, pupuk kimia dan dekomposisi bahan organik yang dapat mempengaruhi warna air. Warna air pada sungai Sengkuang diperkirakan karena adanya embung-embung air yang dibuat di dalam kawasan Kebun Raya Balikpapan yang merupakan hulunya sungai Sengkuang. Pembuatan embung air ini mempengaruhi warna air karena adanya penggenangan air akan mengakibatkan penumpukkan bahan-bahan organik tumbuhan yang dilanjutkan proses dekomposisi bahan organik tersebut. Berdasarkan hasil uji laboratorium pada parameter warna air dari ketiga sungai tersebut mempunyai nilai dibawah 50 TCU standar maksimal untuk air bersih dan dibawah 5 TCU standar air minum.

Total Dissolve Solid (TDS) atau jumlah zat padat terlarut adalah indikator dari jumlah partikel atau zat yang terlarut, baik dalam bentuk senyawa organik ataupun non-organik. Nilai satuan yang dipakai pada umumnya ppm (part per million) atau mg/l (miligram per liter), untuk perhitungan konsentrasi massa kimiawi yang memperlihatkan berapa gram suatu zat pada satu liter cairan. Kadar padatan yang tinggi merupakan indikator bahwa 
kontaminan berbahaya, seperti zat sulfat dan bromida arsenik juga dapat hadir di dalam air tersebut. Kondisi seperti ini terjadi ketika limbah rumah tangga ataupun limbah industri telah mengontaminasi air. Hasil analisis yang ditampilkan pada Tabel 2 menunjukkan nilai TDS pada ketiga sungai tersebut jauh dibawah batas maksimal yang diperbolehkan yaitu $1.500 \mathrm{mg} / \mathrm{L}$. WHO (World Health Organization) menyatakan bahwa selama air masih dalam kategori tawar maka kandungan mineral dalam air tersebut tidak akan memberi pengaruh negatif pada kesehatan. Standar kandungan padatan terlarut dalam air minum yang ditetapkan oleh WHO dibagi dalam lima kriteria level seperti yang diterangkan pada Tabel 3.

Tabel 3. Standar TDS Berdasarkan WHO

\begin{tabular}{cc}
\hline $\begin{array}{c}\text { Kandungan TDS } \\
(\mathbf{m g} / \mathbf{l})\end{array}$ & Penilaian Rasa Air \\
\hline Kurang dari 300 & Bagus sekali \\
$300-600$ & Baik \\
$600-900$ & Bisa diminum \\
$900-1.200$ & Buruk \\
Di atas 1.200 & Berbahaya \\
\hline
\end{tabular}

Sumber: Berdasarkan WHO/SDE/WSH/03.04/16 (WHO, 2003)

Merujuk pada Tabel 3, nilai TDS air sungai Wain, sungai Bugis dan Sungai Sengkuang masuk dalam level Bagus Sekali karena kurang dari 300 mg/L. Sungai Bugis dan sungai Sengkuang memiliki nilai TDS yang sama yaitu $13 \mathrm{mg} / \mathrm{l}$, sedangkan sungai Wain mempunyai nilai TDS paling rendah yatu $7 \mathrm{mg} / \mathrm{l}$. Hal ini dimungkinkan karena DAS Wain masih ada daerah tangkapan airnya yang merupakan hutan primer (virgin forest), sehingga tingkat erosi atau pengikisan tanah pada saat terjadi hujan menjadi lebih rendah dibandingkan kawasan yang lebih terbuka.

\section{Parameter Kimia}

Hasil pengukuran di lapangan dan hasil uji laboratorium kualitas kimia air dari sungai Wain, sungai Bugis dan sungai Sengkuang disajikan dalam Tabel 4 seperti tersebut di bawah ini.

Tabel 4. Kualitas Kimia Air Sungai

\begin{tabular}{clccccc}
\hline No. & $\begin{array}{c}\text { Lokasi Pengambilan Sampel } \\
\text { Air }\end{array}$ & $\mathbf{p H}$ & $\begin{array}{c}\text { Besi } \\
(\mathbf{F e})\end{array}$ & $\begin{array}{c}\text { Kesadahan } \\
\left(\mathbf{C a C O}_{3}\right)\end{array}$ & $\begin{array}{c}\text { Nitrat } \\
\left(\mathbf{N O}_{2}\right)\end{array}$ & $\begin{array}{c}\text { Sulfat } \\
\left(\mathbf{S O}_{4}\right)\end{array}$ \\
\hline 1. & Sungai Wain & 4,42 & 1,08 & 2 & 2,1 & 2,5 \\
2. & Sungai Bugis & 3,67 & 0,76 & 2 & 1,9 & 2,5 \\
3. & Sungai Sengkuang & 5,25 & 0,93 & 8 & 1,0 & 2,5 \\
\hline & Kadar Maksimum Diperbolehkan & $6,5-8,5$ & 1,00 & 500 & 10,0 & 400 \\
& Satuan & - & $\mathrm{mg} / \mathrm{l}$ & $\mathrm{mg} / \mathrm{l}$ & $\mathrm{mg} / 1$ & $\mathrm{mg} / \mathrm{l}$ \\
\hline
\end{tabular}

Potential hydrogen $(\mathrm{pH})$. $\mathrm{pH}$ adalah satu faktor terpenting yang melayani indeks untuk polusi. Nilai $\mathrm{pH}$ mempunyai efek langsung terhadap kehidupan dalam ekosistem (Sari \& Wijaya, 2019). Derajat keasaman (pH) air pada ketiga sungai di dalam kawasan HLSW disajikan pada Tabel 3. Nilai pH terendah terdapat pada sungai Bugis sebesar 3,67, kemudian sungai Wain dengan nilai pH 4,42 dan yang tertinggi pada sungai Sengkuang dengan Nilai pH 5,25. Berdasarkan Peraturan Daerah Provinsi Kalimantan Timur Nomor 02 Tahun 2011, hasil pengukuran pH ini menunjukkan kondisi air sungai Sengkuang memenuhi standar baku mutu kelas I karena nilai $\mathrm{pH}$ diatas 5. Sedangkan air dari sungai Wain dan sungai Bugis masuk standar baku mutu air kelas IV yaitu hanya dapat digunakan 
untuk mengairi sawah. Adanya hujan yang bersifat asam dan aktivitas dari limbah organik di dalam air akan mempengaruhi nilai $\mathrm{pH}$. Ketika kadar limbah organik dalam air tinggi, maka aktivitas mikroorganisme akan terpengaruh. Beberapa bentuk aktivitas mikroorganisme di antaranya seperti fermentasi dari daun-daun, aktivitas tumbuhan air, bahkan pembusukan bangkai yang mengakibatkan penurunan nilai $\mathrm{pH}$ air (Simbolon, 2016).

Menurunnya kualitas perairan salah satunya diindikasikan dengan rendahnya nilai $\mathrm{pH}$ air yang pada akhirnya berpengaruh negatif pada kehidupan biota di dalamnya. Pada nilai $\mathrm{pH}$ rendah $(<4)$, akan mengakibatan banyak tumbuhan air mati karena tidak dapat beradaptasi pada $\mathrm{pH}$ rendah. Hal ini akan membunuh biota yang lainnya, karena jaringan makanan dalam perairan menjadi terganggu (Susana, 2009). Tinggi rendahnya $\mathrm{pH}$ juga dipengaruhi oleh fluktuasi kandungan oksigen ataupun $\mathrm{CO}_{2}$. Kondisi perairan dengan tingkat $\mathrm{pH} \leq 4,8$ dan $\geq 9,2$ pada umumnya sudah dianggap tercemar (Asdak, 2010).

Besi $(\mathrm{Fe})$. Besi dengan bentuk ion Fe3+ sangat mudah larut dalam air. Besi di dalam air dapat menimbulkan gangguan seperti rasa dan bau logam yang amis, menimbulkan warna kecoklat-coklatan pada pakaian putih, meninggalkan noda pada bak-bak kamar mandi dan peralatan lainnya, dapat menyebabkan juga menimbulkan endapan pada bak penampung air (Febrina \& Ayuna, 2015). Disamping itu air yang mengandung zat besi dalam jumlah yang tinggi apabila dikonsumsi dapat menimbulkan rasa mual dan dapat merusak dinding usus halus, bahkan dapat menyebabkan kematian dikarenakan rusaknya dinding usus halus.

Kandungan Fe dalam air dapat bersumber dari dalam tanah sendiri di samping dapat pula berasal dari sumber lain. Besi $(\mathrm{Fe})$ adalah logam essensial yang sangat diperlukan dalam besaran tertentu oleh mahluk hidup, akan menjadi berefek racun ketika berlebih jumlahnya (Supriyantini \& Endrawati, 2015).

Kandungan besi yang melebihi ambang batas kadar besi yang diperbolehkan pada hasil analisis air terdapat pada sungai Wain yaitu sebesar $1,08 \mathrm{mg} / \mathrm{l}$, sedangkan sungai Bugis dan sungai Sengkuang kadar besinya masih dibawah ambang batas yaitu 0,75 mg/l dan $0,93 \mathrm{mg} / \mathrm{l}$. Kandungan besi yang melebihi $1 \mathrm{mg} / \mathrm{l}$ dapat menimbulkan iritasi terhadap mata maupun kulit. Disamping itu, mengakibatkan bau busuk pada air. Gangguan fisik yang ditimbulkan akibat adanya besi terlarut dalam air adalah perubahan warna, bau, dan rasa pada air (Febrina \& Ayuna, 2015).

Kesadahan $\left(\mathrm{CaCO}_{3}\right)$. Kesadahan air adalah jumlah kandungan unsur $\mathrm{Ca} 2+$ dan $\mathrm{Mg} 2+$ dalam air. Pada umumnya kesadahan menggambarkan jumlah milligram calcium carbonate yang terkandung. Dalam pemanfaatannya di rumah tangga ataupun untuk pemanfaatan industri, umumnya kesadahan tidak diinginkan (Astuti et al. 2015).

Berdasarkan Standar Baku Mutu Kesehatan Lingkungan untu Keperluan Sanitasi, batas maksimal kesadahan air adalah $500 \mathrm{mg} / \mathrm{l}$. Air yang mempunyai kesadahan di atas nilai ambang batas yang dibolehkan dapat menimbulkan masalah-masalah kesehatan. Akibat yang dapat ditimbulkan tersebut antara lain adalah dapat mengakibatkan penyumbatan pembuluh darah jantung (cardiovascular desease) dan batu ginjal (Nyoman et al. 2018).

Berdasarkan analisis air di laboratorium terhadap kesadahan air pada ketiga sungai tersebut didapatkan nilai kesadahan yang rendah yaitu sungai Wain sebesar $2 \mathrm{mg} / \mathrm{l}$, sungai Bugis sebesar $2 \mathrm{mg} / \mathrm{l}$ dan sungai Sengkuang sebesar $3 \mathrm{mg} / \mathrm{l}$. Semua nilai tersebut jauh di bawah ambang batas maksimal yang standar kesadahan diperbolehkan. Hal ini menunjukkan bahwa ditinjau dari tingkat kesadahannya air dari ketiga sungai tersebut tidak berbahaya untuk diminum.

Nitrat $\left(\mathrm{NO}_{3}\right)$. Nitrat merupakan salah satu parameter kimia yang mengganggu kualitas perairan dan mempengaruhi kadar kualitas dari perairan (Adesuyi et al., 2015). Nitrat ini mempunyai potensi untuk mengalir menuju sumber air yang berada lebih rendah 
semisal mata air, sungai maupun badan air lainnya sehingga dapat merusak kadar nutrisi dalam air dan akan berpengaruh langsung terhadap keseluruhan kualitas airnya (Bowden et al., 2015).

Nitrat sangat dibutuhkan oleh tanaman sebagai salah satu nutrisi yang penting dalam kadar yang seimbang. Kadar yang berlebihan dapat menimbulkan masalah yang signifikan terhadap kualitas air, mempercepat eutrofikasi dan pertumbuhan tanaman air menjadi lebih pesat sehingga akan membuat dampak pada kadar oksigen terlarut, temperatur, serta parameter lainnya (Irwan et al. 2017).

Hasil yang ditunjukkan dari analisis laboratorium terhadap kandungan nitrat pada air sungai Wain adalah 2,1 mg/l, pada sungai Bugis sebesar $1,9 \mathrm{mg} / \mathrm{l}$, sedangkan pada sungai Sengkuang sebanyak 1,0 mg/l. Berdasarkan Permenkes RI No. 32/MENKES/2017 tentang Standar Baku Mutu Kesehatan Lingkungan, ketiga nilai kadar nitrat tersebut masih di bawah nilai ambang batas yang diperbolehkan yaitu 10,0 mg/l. Nilai baku mutu air pada ketiga sungai tersebut berada dalam kelas 1 sehingga dapat dimanfaatkan sebagai sumber minum.

Sulfat $\left(\mathrm{SO}_{4}\right)$. Ion sulfat merupakan salah satu anion utama di dalam air yang keberadaannya muncul secara alami. Ketersediaan sulfat sebagai salah satu ion penting dalam air dalam jumlah yang besar mempunyai efek yang penting untuk (Erviana et al., 2018).

Apabila sulfat melebihi batas ambang maksimum yang diperbolehkan yaitu sebesar $400 \mathrm{mg} / \mathrm{l}$ maka akan berbahaya bagi kesehatan manusia. Asam sulfat terbentuk dari reaksi antara sulfat dan air melalui oksidasi. Asam sulfat memberi dampak negatif berupa iritasi pada kulit dan mata jika terkena, serta dapat mengakibatkan gangguan pernapasan (Vogel, 1985).

Berdasarkan hasil analisis laboratorium, kadar sulfat dalam sampel air dari ketiga sungai tersebut mempunyai nilai yang sama yaitu 2,5 mg/l. Kadar sulfat tersebut masih memenuhi persyaratan Permenkes RI No. 32/MENKES/2017 untuk dipergunakan sebagai sumber air minum.

Berdasarkan hasil pengukuranan di lapangan dan analisis di laboratorium terhadap kualitas air menunjukkan bahwa kondisi kualitas air sungai Wain, sungai Bugis dan sungai Sengkuang dalam kawasan HLSW hampir semuanya mempunyai nilai di bawah ambang batas yang diperbolehkan kecuali nilai kadar $\mathrm{pH}$ dari ketiga sungai tersebut yang tidak memenuhi standar baku mutu sumber air minum. Secara umum kondisi air sungai tersebut masuk dalam mutu air kelas I, artinya layak untuk dipergunakan untuk memenuhi berbagai kebutuhan air masyarakat. Sedangkan untuk mengatasi kondisi derajat keasaman air dapat didahului dengan perlakuan air ( water treatment) untuk meningkatkan nilai $\mathrm{pH}$.

\section{Parameter Biologi}

Dalam penelitian ini pengujian kualitas air untuk parameter biologi menggunakan indikator kandungan Total Coliform dan kandungan bakteri Escherecia Coli (E. Coli). Sumber adanya bakteri coliform dapat berasal dari limbah, residu pertanian, kontaminasi dengan kotoran manusia/binatang, dan sebagainya. Dari hasil uji laboratorium menunjukkan air sungai-sungai tersebut telah tercemar karena ditemukan adanya bakteri coliform (Tabel 5).

Total Coliform. Parameter Total Coliform berguna untuk mengetahui jumlah bakteri Escherecia coli dan aerobakter yang terkandung dalam air. Bakteri Escherecia coli umumnya berasal dari kotoran manusia, bakteri ini dapat meresap ke dalam tanah dan ikut masuk dalam sistem air tanah. Sementara aerobakter umumnya berasal dari hewan atau tanaman yang telah terdekomposisi dalam 
tanah. Bakteri ini berbahaya apabila dikonsumsi masuk karena dapat mengganggu sistem pencernaan (Nuraini et al. 2017).

Tabel 5. Kualitas Biologi Air Sungai

\begin{tabular}{clccc}
\hline No. & Lokasi Pengambilan Sampel Air & Total Coliform & Escherecia Coli & Kesesuaian \\
\hline 1. & Sungai Wain & 350 & 3,6 & Tidak sesuai \\
2. & Sungai Bugis & 920 & 4,0 & Tidak sesuai \\
3. & Sungai Sengkuang & 350 & 2,0 & Tidak sesuai \\
\hline & Kadar Maksimum Diperbolehkan & 50 & 0,0 & \\
& Satuan & Jumlah/100 ml & Jumlah $/ 100 \mathrm{ml}$ & \\
\hline
\end{tabular}

Hasil analisis total coliform pada air dari ketiga sungai tersebut dapat dilihat pada Tabel 4, semua sampel air menunjukkan nilai di atas jumlah maksimum bakteri yang diperbolehkan. Sungai Bugis mempunyai jumlah total coliform yang tertinggi yaitu 920, sementara sampel total coliform pada sungai sungai Wain dan sungai Sengkuang mempunyai jumlah yang sama yaitu 350. Banyaknya bakteri total coliform dalam sampel air kemungkinan diakibatkan di dalam sungai-sungai tersebut banyak terkontaminasi dengan bahan organik. Kandungan coliform total dapat diturunkan dengan menambahkan kaporit dalam air (Mariyana et al. 2015).

\section{Upaya Perlindungan Hutan Lindung untuk Kelestarian Sumber Daya Air}

Parameter yang digunakan dalam pengujian kualitas air sungai pada penelitian ini adalah parameter fisik, parameter kimia dan parameter biologi. Analisis laboratorium untuk beberapa parameter tersebut dilakukan di UPTD Laboratorium Kesehatan Daerah, Dinas Kesehatan Kota Balikpapan. Mengingat besarnya fungsi pokok hutan lndung sebagai perlindungan sistem penyangga kehidupan sebagai pengatur tata air, pengendali erosi, pencegah intrusi air laut serta pemelihara kesuburan tanah, maka perlindungan terhadap HLSW sangat penting dilakukan untuk menanggulangi dan mengurangi pencemaran yang dapat berakibat kerusakan lingkungan terutama dalam upaya menjaga kuantitas dan kualitas air sungai yang ada dalam kawasan. Komponen biotik dan abiotik sebagai pembentuk ekosistem hutan mempunyai pengaruh yang nyata pada siklus hidrologis (Sulistyorini et al. 2017). Dalam pengelolaan hutan hal yang perlu menjadi perhatian salah satunya adalah kondisi fisik lingkungan karena lingkungan bersifat dinamis dan senantiasa berubah (Matatula et al. 2019a). Beberapa bentuk upaya perlindungan yang dapat dilakukan yaitu pertama dapat dilakukan dengan mengadakan kegiatan konservasi melalui kegiatan penanaman areal-areal kosong terutama pada daerah tangkapan air (DTA) untuk meningkatkan luas tutupan lahan di kawasan HLSW. Daerah tangkapan air tersebut perlu direboisasi atau pengayaan dengan menggunakan jenis tanaman yang dapat menjaga keberadaan sumber air seperti pohon Aren, Gayam, Kedawung, Trembesi, Beringin, Elo, Preh, Bulu, Benda, Kepuh, Randu, Jambu Air, Jambu Alas, Bambu, atau Picung, agar air dapat terjaga ketersediaannya sepanjang tahun (Pratiwi et al. 2020; Yuliantoro et al. 2016). Kedua, memperbaiki pola tanam masyarakat $\mathrm{HKm}$ di blok pemanfaatan, serta mengurangi penggunaan pupuk kimia serta penggunaan pestisida. Pupuk kimia yang tidak terserap oleh tanaman dan pestisida akan larut terbawa air hujan dan akan mencemari air sungai. Ketiga, pemanfaatan sumber daya air di HLSW harus mempertimbangkan besarnya debit air yang ada agar tidak terjadi kekeringan ketika musim kemarau tiba. Keempat perlu sebuah peraturan daerah untuk pemanfaatan air dari HLSW agar para pemanfaat air mempunyai konstribusi dalam upaya pengelolaan HLSW sehingga kelestarian sumber daya air dari HLSW dapat terjaga dengan baik dan lestari. 


\section{Kesimpulan}

Kuantitas air sungai di dalam kawasan HLSW menunjukkan debit air yang berbedabeda pada setiap sungainya akan tetapi termasuk dalam kategori potensi besar sehingga layak sebagai sumber penyedia air baku. Pada hasil penilaian kualitas air terdapat dua nilai parameter kimia air sungai di kawasan HLSW yang tidak sesuai standar baku yaitu nilai pH dan kadar logam (Fe), serta semua sungai tercemar oleh bakteri Escherecia coli, sehingga tidak disarankan untuk dikonsumsi secara langsung.

Hasil penilaian kuantitas dan kualitas air sungai di kawasan HLSW ini dapat menjadi bahan pertimbangan bagi pemerintah Kota Balikpapan untuk mengembangkan pemanfaatan air sungai di kawasan HLSW ditingkatkan menjadi sumber penyedia air baku bagi masyarakat Kota Balikpapan. Disamping itu hasil penelitian ini dapat sebagai landasan bagi pengelola HLSW dan para pemangku kepentingan dalam pengambilan kebijakan pengelolaan HLSW guna menjamin keberlanjutan sumber daya air dan kelestarian HLSW, serta memperkuat kondisi sosial ekonomi masyarakat di sekitar HLSW.

\section{Ucapan Terima Kasih}

Penulis mengucapkan terima kasih kepada Pemerintah Provinsi Kalimantan Timur yang telah memberikan pendanaan untuk penelitian ini melalui skema Pembiayaan Beasiswa PNS Tugas Belajar. Penulis juga mengucapkan terimakasih kepada managerial dan forest ranger Yayasan Pro Natura, adik-adik mahasiswa Fahutan Universitas Mulawarman yang telah membantu dalam pelaksanaan penelitian ini. Tidak lupa pula penulis sampaikan terimakasih sebesar-besarnya kepada Dinas Kehutanan Provinsi Kalimantan Timur, UPTD KPHL Balikpapan dan UPTD KPHP Bongan atas bantuan fasilitas dan partisipasinya dalam pelaksanaan penelitian ini.

\section{Daftar Pustaka}

Adesuyi, A. A., Nnodu, V. C., Njoku, K. L., \& Jolaoso, A. (2015). Nitrate and phosphate pollution in surface water of nwaja creek, Port Harcourt, Niger Delta, Nigeria. International Journal of Geology, Agriculture and Environmental Sciences, 3(5), 14-20.

Aronggear, T. E., Supit, C. J., \& Mamoto, J. D. (2019). Analisis kualitas dan kuantitas penggunaan air bersih PT. Air Manado Kecamatan Wenang. Jurnal Sipil Statik, 7(12), 1625.

Asdak, C. (2010). Hidrologi dan pengelolaan daerah aliran sungai. Gadjah Mada University Press.

Astuti, D. W., Rahayu, M., \& Rahayu, D. S. (2015). Penetapan kesadahan total (CaCO3) air sumur di Dusun Cekelan Kemusu Boyolali dengan metode kompleksometri. Jurnal Kesehatan Masyarakat, 9(2), 119-124. doi:10.12928/kesmas.v9i2.2273.

Bowden, C., Konovalske, M., Allen, J., Curran, K., \& Touslee, S. (2015). Water quality assessment: The effects of land use and land cover in urban and agricultural land. Kansas State University.

Dako, F. X., Purwanto, R. H., Rahayu, L. F. W., \& Sumardi. (2019). Kerusakan antropogenik kawasan Hutan Lindung Mutis Timau dan upaya penanggulangannya di Pulau Timor Bagian Barat. Jurnal Pengelolaan Sumberdaya Alam dan Lingkungan, 9(2), 437-455. doi:10.29244/jpsl.9.2.437-455.

Erviana, D., Budaya, A. W., Hariani, S., Winda, A., \& Sari, L. Y. (2018). Analisis kualitatif kandungan sulfat dalam aliran air dan air danau di Kawasan Jakabaring Sport City Palembang. ALKIMIA: Jurnal Ilmu Kimia dan Terapan, 2(2), 1-4. doi:10.19109/alkimia.v2i2.2986.

Febrina, L., \& Ayuna, A. (2015). Studi penurunan kadar besi (Fe) dan mangan (Mn) dalam air tanah menggunakan saringan keramik. Jurnal Teknologi, 71), 36-44.

Hasrianti, \& Nurasia. (2016). Analisis warna, suhu, pH dan salinitas air sumur bor di Kota Palopo. Prosiding Seminar Nasional ISSN 2443-1109, 2(1), 747-753.

Irwan, M., Alianto, \& Toja, Y. T. (2017). Kondisi fisika kimia air sungai yang bermuara di Teluk Sawaibu 


\section{Analisis Kuantitas dan Kualitas Air dalam Pengembangan Pemanfaatan Sumber Daya Air. . .}

Kabupaten Manokwari. Jurnal Sumberdaya Akuatik Indopasifik, 1(1), 81-92. doi:10.30862/jsai-fpikunipa.2017.vol.1.no.1.23.

Kementerian Kesehatan. (2017). Peraturan Menteri Kesehatan Republik Indonesia Nomor 32 Tahun 2017 tentang standar baku mutu kesehatan lingkungan dan persyaratan kesehatan air untuk keperluan higiene sanitasi, kolam renang, solus per aqua dan pemandian umum. Kementerian Kesehatan.

KPHL Balikpapan. (2017). Rencana pengelolaan hutan jangka panjang kesatuan pengelolaan hutan lindung (KPHL) Balikpapan Tahun 2018-2027. Pemerintah Provinsi Kalimantan Timur UPTD KPHL Balikpapan.

Kubah, L. Q., Rosdiana, \& Khadarsyah. (2018). Kelembagaan pengelolaan kawasan hutan lindung sungai wain pasca undang - undang nomor 09 tahun 2015 tentang pemerintah daerah perubahan ke-2 atas undang undang nomor 23 tahun 2004 tentang pemerintah daerah. Jurnal De Jure, 19(I), 41-63.

Mariyana, M., Joko, T., \& Nurjazuli, N. (2015). Efektifitas kaporit dalam menurunkan kadar amoniak dan bakteri coliform dari limbah cair RSUD Tugurejo Semarang. Jurnal Kesehatan Masyarakat, 3(1), 533-539.

Matatula, J. (2009). Upaya rehabilitasi lahan kritis dengan penerapan teknologi agroforestry sistem silvopastoral di Desa Oebola Kecamatan Fatuleu Kabupaten Kupang. Inotek: Jurnal Inovasi Ilmu Pengetahuan, Teknologi, dan Seni. 13(1), 63-74.

Matatula, J., Poedjirahajoe, E., Pudyatmoko, S., \& Sadono, R. (2019a). Keragaman kondisi salinitas pada lingkungan tempat tumbuh mangrove di Teluk Kupang, NTT. Jurnal Ilmu Lingkungan, 173), 425. doi:10.14710/jil.17.3.425-434.

Matatula, J., Poedjirahajoe, E., Pudyatmoko, S., \& Sadono, R. (2019b). Sebaran spasial kondisi lingkungan hutan mangrove di Pesisir Pantai Kota Kupang. Journal of Natural Resources and Environmental Management, 9(2), 467-482. doi:10.29244/jpsl.9.2.467-482.

Maulana, A. (2016). Memberdayakan rencana detail tata ruang (RDTR) kawasan strategis Hutan Lindung Sungai Wain dan Sungai Manggar tahun 2015-2035 dalam mereduksi ancaman kelestarian lingkungan. Jurnal Wilayah dan Lingkungan, 4(2), 123-132. doi:10.14710/jwl.4.2.123-132.

Mersianty, M., \& Mahfud, M. (2017). Pengembangan infrastruktur air baku Kota Balikpapan. JTT (Jurnal Teknologi Terpadu), 5(2), 151-158. doi:10.32487/jtt.v5i2.275.

Ningsih, S. R., Putra, E. G. E., \& Goembira, F. (2020). Analisis ketersediaan, kebutuhan dan kualitas air pada DAS Batang Merao. Jurnal Ilmu Lingkungan, 18(3), 545-555. doi:10.14710/jil.18.3.545-555.

Nuraini, R. A. T., Endrawati, H., \& Maulana, I. R. (2017). Analisis kandungan logam berat kromium (Cr) pada air, sedimen dan kerang hijau (Perna viridis) di Perairan Trimulyo Semarang. Jurnal Kelautan Tropis, 201), 48-55. doi:10.14710/jkt.v20i1.1104.

Nyoman, R. N., Amri, I., \& Harun, H. (2018). Perbandingan kadar kesadahan air PDAM dan air sumur suntik Kelurahan Tondo Kota Palu tahun 2017. MEDIKA TADULAKO Jurnal Ilmiah Kedokteran, 5(3), 12-21.

Oktavianto, A., Nurhayati, N., \& Suswati, E. (2014). Evaluasi keamanan sumber air minum Desa Mojo Kecamatan Padang Kabupaten Lumajang. Jurnal Agroteknologi, 8(2), 185-191.

Pathibang, M. R., Aryani, N. K. A. D., \& Matatula, J. (2019). Konservasi sumber mata air Baumata berbasis masyarakat lokal. Jurnal Pengabdian Kepada Masyarakat, 4(1), 41-45. doi:10.26905/abdimas.v4i1.3238.

Pemerintah Kota Balikpapan. (2014). Buku laporan status lingkungan hidup Kota Balikpapan 2014. Pemerintah Kota Balikpapan, Provinsi Kalimantan Timur.

Permatasari, R., Arwin, \& Natakusumah, D. K. (2017). Pengaruh Perubahan penggunaan lahan terhadap rezim hidrologi DAS (Studi Kasus: DAS Komering). Jurnal Teknik Sipil ITB, 24(1), 91-98. doi:10.5614/jts.2017.24.1.11.

Poedjirahajoe, E., \& Matatula, J. (2019). The physiochemical condition of mangrove ecosystems in the Coastal District of Sulamo, Kupang, East Nusa Tenggara, Indonesia. Jurnal Manajemen Hutan Tropika, 25(3), 173-184. doi:10.7226/jtfm.25.3.173.

Pohan, D. A. S., Budiyono, B., \& Syafrudin, S. (2016). Analisis kualitas air sungai guna menentukan peruntukan ditinjau dari aspek lingkungan. Jurnal Ilmu Lingkungan, 14(2), 63-71. doi:10.14710/jil.14.2.63-71.

Pratiwi, Narendra, B. H., \& Wardani, M. (2020). Pemilihan jenis pohon untuk konservasi tanah dan air dalam rangka pemulihan fungsi daerah aliran sungai. In Pratiwi, B. H. Narendra, \& A. G. Pamungkas (Eds.), Bunga Rampai. Dukungan IPTEK Rehabilitasi Hutan dan Lahan dalam Pemulihan Fungsi Daerah Aliran Sungai (1st ed., Issue August, pp. 47-69). IPB Press. 
Reddy, D. H. K., \& Lee, S. M. (2012). Water pollution and treatment technologies. Journal of Environmental \& Analytical Toxicology, 2(5). doi:10.4172/2161-0525.1000e103.

Sari, E. K., \& Wijaya, O. E. (2019). Penentuan status mutu air dengan metode indeks pencemaran dan strategi pengendalian pencemaran Sungai Ogan Kabupaten Ogan Komering Ulu. Jurnal Ilmu Lingkungan, 173), 486-491. doi:10.14710/jil.17.3.486-491.

Sarminah, S., Anugerah, D. R., Aipassa, M. I., \& Din, A. (2020). Kualitas air pada DAS Bugis dan DAS Wain di Kawasan Hutan Lindung Sungai Wain Balikpapan. ULIN: Jurnal Hutan Tropis, 4(2), 77. doi:10.32522/ujht.v4i2.4224.

Simbolon, A. R. (2016). Pencemaran bahan organik dan eutrofikasi di Perairan Cituis, Pesisir Tangerang. Jurnal Pro-Life, 3(2), 109-118.

Sittadewi, E. H. (2008). Identifikasi vegetasi di koridor Sungai Siak dan peranannya dalam penerapan metode bioengineering. Jurnal Sains dan Teknologi Indonesia, 10(2), 112-118.

Sudia, L. B., Sinukaban, N., Purwanto, Y. J., Sanim, B., \& Tarigan, S. D. (2011). Analisis alternatif penggunaan lahan untuk menjamin ketersediaan air di DAS Konaweha Provinsi Sulawesi Tenggara. Sains Tanah Jurnal Ilmiah Ilmu Tanah dan Agroklimatologi, 8(2), 73-88.

Suheri, A., Kusmana, C., Purwanto, M. Y. J., \& Setiawan, Y. (2019). Model prediksi kebutuhan air bersih berdasarkan jumlah penduduk di Kawasan Perkotaan Sentul City. Jurnal Teknik Sipil dan Lingkungan, 4(3), 207-218. doi:10.29244/jsil.4.3.207-218.

Sulistyorini, I. S., Edwin, M., \& Arung, A. S. (2017). Analisis kualitas air pada sumber mata air di Kecamatan Karangan dan Kaliorang Kabupaten Kutai Timur. Jurnal Hutan Tropis, 4(1), 64. doi:10.20527/jht.v4i1.2883.

Supriyantini, E., \& Endrawati, H. (2015). Kandungan logam berat besi (Fe) pada air, sedimen, dan kerang hijau (Perna viridis) di Perairan Tanjung Emas Semarang. Jurnal Kelautan Tropis, 18(1), 38-45.

Susana, T. (2009). Tingkat keasamanan $(\mathrm{pH})$ dan oksigen terlarut sebagai indikator kualitas perairan Sekitar Muara Sungai Cisadane. Indonesian Journal of Urban and Enviromental Technology, 5(2), 33-39. doi:10.25105/urbanenvirotech.v5i2.675.

Triatmodjo, B. (2010). Hidrologi terapan. Yogyakarta: Beta Offset.

Vogel, A. I. (1985). Analisis anorganik kualitatif makro dan semimikro (5th ed.). Kalman Media Pusaka.

Wahid, A. (2009). Analisis faktor-faktor yang mempengaruhi debit Sungai Mamasa Sulawesi Selatan. Jurnal Sains dan Teknologi, 6(1), 41-58.

WHO. (2003). Total dissolved solids in drinking-water: Background document for development of WHO guidelines for drinking-water quality. WHO Guideline WHO/SDE/WSH/03.04/16. World Health Organization.

Widiyanto, A. F., Yuniarno, S., \& Kuswanto, K. (2015). Polusi air tanah akibat limbah industri dan limbah rumah tangga. Jurnal Kesehatan Masyarakat, 10(2), 246-254. doi:10.15294/kemas.v10i2.3388.

Yuliantoro, D., Dwiatmoko, B., \& Siswo. (2016). Pohon sahabat air. Balai Penelitian dan Pengembangan Teknologi Pengelolaan Daerah Aliran Sungai.

Yusuf, S. (2010). Nilai ekonomi air Hutan Lindung Sungai Wain di Balikpapan Kalimantan Timur. Jurnal Kehutanan Tropika Humida, 3(2), 211-216. 